\title{
Solution of environmental problems in human settlements caused by negative effect of SDW landfills
}

\author{
Yelena Stupnikova ${ }^{1}$, and Ksenia Popova ${ }^{1, *}$ \\ ${ }^{1}$ Federal State Budgetary Educational Institution of Higher Professional Education Moscow State \\ University of Railway Engineering (MIIT), 9/9 Obraztsova st., 127994, Moscow, Russia
}

\begin{abstract}
Environmental protection in the modern world is becoming one of the top priorities of state. Dynamic development of metropolises causes increase of trash volume in landfills, which in turn leads to pollution of air, soil, ground and surface waters, increases the risk of infection spreading to environment and harms public health. This is why it is needed to design new landfill facilities beforehand, which comply with requirements in place; timely reclamate landfills, when they are filled to design level; perform complex recovery of economic value land used as solid domestic waste landfills, and hand over the plots for further intended use.
\end{abstract}

\section{Introduction}

Year 2017 in Russia is dedicated to ecological issues, to drawing attention to problems of pollution of large cities with industrial and domestic waste. In this regard, reclamation of landfills inside settlements becomes specifically important. Furthermore, there arises the need to apply modern technologies to use solid domestic waste in business activity.

It should be noted that while there are many definitions of solid domestic waste, the present study uses the following: "solid domestic waste includes waste from residential and public buildings, commercial, entertainment, sport, and other establishments (including waste from current repair of flats), waste from local heating units, sweepings, fallen leaves from cartilage, and bulky waste" [1].

\section{Literature review}

According to official papers approved by a Decree of the President of Russia as № 7 January 5, 2016, about 18 billion rubles were provided to implement a new system of waste management.

According to "Problem analysis and evaluation of production and consumer waste management in Russia", Russia produces 90 bln tons of waste per year, which mass up in area total of $4 \mathrm{mln}$ ha. Every year $0.4 \mathrm{mln}$ ha are provided for waste dumping, total waste volume is increased for 5 bln tons every year. $91 \%$ of waste are the byproduct of mineral

\footnotetext{
*Corresponding author: k.popova@miit-ief.ru
} 
resources extraction, $4.3 \%$ are associated with metallurgy, $1.5 \%$ - with production and transport of energy, gas and water, $0.3 \%$ - with construction, $0.6 \%$ - with chemical industry, $2.3 \%$ made up of other waste, including solid domestic waste.

There are more than 1000 waste landfills, 15000 authorized dumping grounds, 17000 unauthorized dumping grounds, and 13000 unauthorized garbage dumps in Russia. The country recycles less than $40 \%$ of industrial waste, and less than $10 \%$ of solid domestic waste. This is performed by 40 waste incineration plants, 243 waste recycling plants, and 53 waste sorting complexes [2-4].

\section{Materials and methods}

A dangerous ecological situation rose at the Kuchino SDW landfill, located in Balashikha, Moscow oblast. It was opened in 1964 at the place of depleted clay pit, was receiving up to 600000 tons of waste per year, and had total area of 59 ha.

Presently there are modern residential areas and village Fenino in the immediate vicinity $(200 \mathrm{~m})$ of the landfill, which is violation of rules concerning sanitary protection zone of the landfill. According to SanPiN 2.1 2.1.1.1200-03, width of sanitary protection zone of a SDW landfill equals $500 \mathrm{~m}$ for $2^{\text {nd }}$ class enterprises. Failure to comply with rules and regulations under applicable law causes negative effect on life comfort and public health.

Lack of reliable information about quantity and morphological composition of waste, caused by bad logging of SDW acceptance, substantially hinders reclamation works. Reclamation of such dumping grounds demands a lot of preparatory study and comprehensive engineering surveys (hydrogeologic, geologic, soil, atmosphere, radiological, etc.). Kuchino SDW landfill was closed promptly in compliance with the order of the President of Russian Federation. Waste volumes sent there have been distributed between nearby SDW sites, taking heavy load already, and transport costs increased. These factors provoke appearance of unauthorized dumping grounds, which are set and used without meeting any requirements for environmental protection and public health.

Globally, there are four main methods widely used: burial in dumping grounds (landfills), incineration, recycling and composting [5], Fig. 1.



Fig. 1. Methods of SDW neutralization in various countries, $\%$. 
In Russia the main method of waste neutralization is burying them on-site, due to mainly economical criterion [6], Table 1.

Table 1. Choice of optimal reclamation technology.

\begin{tabular}{|c|c|c|c|c|c|}
\hline \multirow{2}{*}{$\begin{array}{l}\text { Technological } \\
\text { methods of } \\
\text { reclamation }\end{array}$} & \multicolumn{4}{|c|}{ Criteria of choice } & \multirow[t]{2}{*}{ Points total } \\
\hline & ecological & economical & time & technological & \\
\hline $\begin{array}{l}\text { Extraction, } \\
\text { removal and } \\
\text { secure burial }\end{array}$ & 3 & 1 & 1 & 1 & 6 \\
\hline $\begin{array}{l}\text { On-site } \\
\text { disposal }\end{array}$ & 2 & 2 & 2 & 2 & 8 \\
\hline $\begin{array}{l}\text { On-site waste } \\
\text { fixation }\end{array}$ & 1 & 3 & 3 & 3 & 10 \\
\hline
\end{tabular}

Points meaning: 1 - acceptable; 2 - good; 3 - excellent.

Reclamation of a landfill is performed after it achieves persistent steady condition in two stages: technical and biological.

Technical stage of reclamation includes surveys of dumping ground soil and its effect on environment, and preparation of landfill territory for further intended use.

Biological stage of reclamation follows after that: it includes a set of agrotechnical and phytomelioration works to restore disturbed land.

After the works necessary to guarantee full environmental protection and ecological public safety have been performed, it is possible to create a developed area [7].

There are already large successful projects of elimination of waste burial negative effects, and restoring areas previously used as landfills. In USA and Finland it is popular to create sport facilities and recreation parks in such places. With special technologies, what once were waste landfills turn into popular places that are safe for human health [8].

Organization of ski resorts, sports grounds, family recreation areas, parks and petting zoos may be relevant for Kuchino SDW landfill. Modern residential areas are actively being built in its immediate vicinity, and there are enough new houses already, populated by mostly young families, which are not always able to travel for holidays, and could provide the demand needed.

Commercially, building of ski resorts around metropolises is very profitable. Balashikha is located not far from the eastern border of Moscow. It is the largest city in Moscow oblast. Total population of Balashikha (considering also the town Zheleznodorozhny, which was made part of it in 2015) is 450771 people. The city is rapidly developing thanks to increase in new housing supply. According to Rosstat (RBK calculations), 55\% of Balashikha citizens work outside of it, mostly in Moscow, and therefore are able to use ski resorts. Creation of such project will definitely appeal for family recreation.

As recreation areas will be organized on the domestic waste landfill, it becomes vital to guarantee health and safety of its visitors. It is necessary to cover the dumping ground with nonwoven geotextile and additional layers of barrier materials, to organize strict control of air, water and soil quality.

Reclamation of used-up landfills is a viable method of environmental protection, but it cannot solve the problem of waste elimination globally. The latter demands significant land resources and large sums for restoration of natural balance. Hence the reason to develop modern complex approaches that consider all the newest scientific and technological advances.

In scientific community, waste is recently being actively considered a renewable energy source. Special pyrolysis plants allow using biogas from chemical reactions as a power resource [9]. 
A key role in solving problems of environmental ecology may be played by development of business activity aimed to return SDW for repeated use - recycling. Analysis of morphological composition of SDW shows significant volumes of components available for recycling, but their use is hindered by absence of quality sorting system with technical developments of separation, and low ecological culture of population [10], Fig. 2.

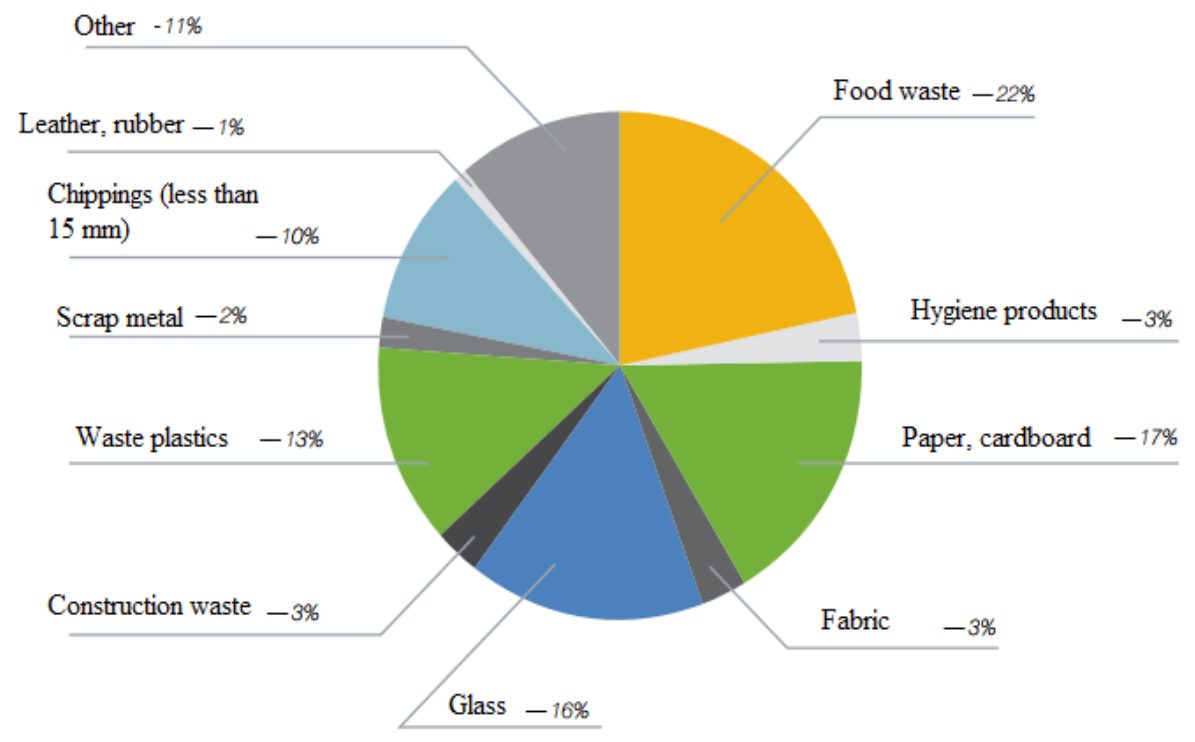

Fig. 2. Morphological composition of SDW of Moscow region, mass $\%$.

\section{Results}

Civilizational approach to solution of the materials re-use problem should lie in implementation of separate waste collection system, which would make waste a unique material in a resource-constrained environment.

Currently there are a lot of SDW recycling technologies that are environmentally safe, do not demand additional external power sources, and create new goods from recycled materials. Modern complete plants are able to recycle up to $98 \%$ of SDW [11].

Comprehensive strategy of SDW management becomes relevant not only for solving complex ecological and social questions, but development of cost-effective projects obtains the same importance [12].

As an example, we will compare profit-making capacity of traditional waste burial onsite, and a method of SDW recycling on plants aimed to gain maximum profit from depleted leftovers, provided that waste volume received was the same.

\subsection{Profit-making capacity of Kuchino city SDW landfill (burial on-site)}

According to service tariff for garbage disposal, price for $1 \mathrm{~m} 3$ of waste $=66.19$ rub.

The landfill was receiving 600000 tons of waste per year.

1 ton of waste $=5 \mathrm{~m} 3$ (Assumed to calculate work amount as per contract with public utilities service provider).

The landfill profit-making capacity per year:

$600000 * 5 * 66.19=198570000 \mathrm{rub}$. 


\subsection{Profit-making capacity of an industrial complex producing energy resources and other goods from municipal waste}

Implemented technology of destruction of organic waste in catalytic medium yielding highquality market-ready end products is conceptually new feature in this project. Waste recycling complexes are wholly autonomous and self-sustained. According to Health Inspection Services conclusion, emissions are significantly lower than maximum permissible concentrations.

For recycling 100 tons of SDW (processing depth 95\%) the yield is 94 tons of secondary raw materials, Table 2 .

Table 2. Composition of recycled products of the energy resources complex.

\begin{tabular}{|c|c|c|}
\hline Product & Unit of measurement & Quantity \\
\hline Biogas, methane $60 \%$ & cubic metre & 8000 \\
\hline $\begin{array}{l}\text { Liquified gas for domestic } \\
\text { use }\end{array}$ & ton & 3.4 \\
\hline Diesel fuel component & cubic metre & 3.4 \\
\hline Petrol component & cubic metre & 5.6 \\
\hline Solid fuel briquettes & ton & 26 \\
\hline Metal & ton & 4 \\
\hline Waste glass & ton & 2.8 \\
\hline $\begin{array}{ll}\text { High-quality } & \text { organic } \\
\text { fertilizer } & \end{array}$ & ton & 1.7 \\
\hline Liquid organic fertilizer & ton & 22 \\
\hline Construction materials & ton & 18.8 \\
\hline Total & ton & 94 \\
\hline
\end{tabular}

Profit from 1 ton of garbage is 7800 rub on the average.

Yearly profit from recycling 600000 tons of garbage will be equal:

$600000 * 7800=4680000000 \mathrm{rub}$.

Therefore, profit-making capacity while using SDW recycling may be more than 20 times higher in comparison with the burial method presently used.

\section{Discussion}

Therefore, it is possible to draw conclusions, that transition from SDW burial to complex recycling into products and secondary raw materials is not only beneficial for ecology (decreased harmful effect to environment, less area is used as waste landfills, natural resource conservation), but also has positive economical effect.

It is needed to perform comprehensive analysis of possibilities for creating attractive investment conditions of public-private partnerships in SDW management.

An additional source of financing for waste neutralization may be found in creating a fund for landfill reclamation, in which a part of payments for domestic waste elimination will be accumulated.

\section{Conclusions}

Special emphasis in maintaining ecological safety should be placed on strict monitoring and regular control of compliance with the requirements of environmental protection by local and regional bodies. Last, but not the least, is education of community and events for drawing attention to the problem of elimination and recycling of all kinds of waste. 
All these measures as a whole provide for public health safety, qualitative improvement of environment and its preservation for future generations.

\section{References}

1. O.V. Sheveleva, The effect of big numbers 8(134), 5-8 (2017)

2. D.V. Stalinsky, A.Z. Ryzhavsky, A.S. Rudyuk, A.V. Zimoglyad, The strategy of practical solid domestic waste disposal 8(134), 44-47 (2017)

3. V. Lukinov, An. Mottaeva, Online magazine of science 2 (21), 54 (2014)

4. M.Y. Bikbau, Ekologicheskiy vestnik Rossii 12, 48-57 (2009)

5. E. Chibisova, Economy and entrepreneurship 5-2(58-2), 600-603 (2015)

6. L.N. Beldeyeva, Y.S. Lazutkina, L.F. Komarova, The environmentally sound waste handling (Azbuka, Barnaul, 2009)

7. L.A. Gorbachyova, Energiya: Ekonomika, tekhnologiya, ekologiya 7, 49-54 (2009)

8. V.V. Babak, The geo-ecology of solid domestic waste landfills of the Moscow Oblast. Extended abstract of PhD dissertation (Lomonosov Moscow State University, Moscow, 2009)

9. S.O. Lavriyenko, M.V. Balanovsky, Tvyordyie bytovyie otkhody: elektronny zhurnal 8 (134), 48-54 (2017)

10. E. Vasilyeva, Economy and entrepreneurship 3-2(80-2), 973-976 (2017)

11. A.M. Belyaev, Tvyordyie bytovyie otkhody: elektronny zhurnal 8(134), 51-53 (2017)

12. V.D. Bashirov, M.Z. Gulak, R.F. Sagitov, Tekhnicheskiye nauki 6, 65-67 (2012) 